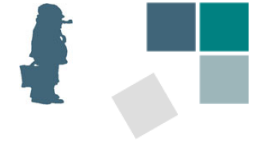

www.accedoverlag.de

\title{
Adam Smith's Model of Man and Some of its Consequences
}

\author{
Manfred J. Holler \\ Institute of SocioEconomics, University of Hamburg, Germany \\ (eMail: holler@econ.uni-hamburg.de)
}

\begin{abstract}
This papers discusses the relationship of the 'model of man' presented by Adam Smith in The Theory of Moral Sentiments (1759) and the assumptions about human behaviour which are quintessential for his An Inquiry into the Nature and Causes of the Wealth of Nations (1776/77). It is argued that Smith's observation of a 'propensity to truck, barter and exchange one thing for another' does not in general hold for human behaviour. Moreover, there appears to be an inherent conflict with 'sympathy', the key concept proposed in The Theory of Moral Sentiments, if we interpret it as the source of social evaluation, selfevaluation and individual action. Following Karl Polanyi's critical comments in The Great Transformation (1944), we will discuss some of the consequences of this incongruence for the philosophical foundations of modern economics and economic policy.
\end{abstract}

Keywords Models of Man, social ethics, impartial spectator

\section{Introduction}

There is hardly a more controversial writer in the history of economics and the social sciences than Adam Smith inasmuch as very different 'social religions' identify their roots with his work. By many he is hailed as a prophet of free markets while others point to his elaborate moral theory and the fundamental social dimension of his thought (and life). One might argue that this is due to the fact that one group studied The Theory of Moral Sentiments (1759) while the other had his An Inquiry into the Nature and Causes of the Wealth of Nations (1776/77) at their bedside. It is very likely that only a very small percentage of those who refer to Adam Smith to sell their ideas about how to improve the world have actually read either of these books; and certainly very few have read both - let alone having read his correspondence or Lectures on Jurisprudence. The latter

(C) 2006 Accedo Verlagsgesellschaft, München.

ISBN 3-89265-063-2 ISSN 0943-0180 
were compiled from notes of zealous students who attended his lectures at Glasgow University during the years before he went on the two-year grand tour of France. However, it seems superficial to blame the potential readership for not adequately accomplishing its obligation when it comes to Adam Smith. If there is an obvious shortcoming, and most ardent free trade proponents do not even study the Wealth of Nations, then there could also be the reason for this.

A possible answer to this puzzle could be that Adam Smith proposed at least two 'models of man': the model that he proposed to form the core of his economic theory is perhaps not particularly convincing from an empirical point of view and the second model, introduced in his Theory of Moral Sentiments, does not reach far enough to evaluate the outcome which corresponds to his economic theory from a social point of view. Adam Smith is known to have been a keen observer who elegantly generalized his observations in the form of theoretical concepts. However, in this paper, I will argue that his observation of a 'certain propensity of human nature' ... 'the propensity to truck, barter and exchange one thing for another' (117), which is at the heart of the Wealth of Nations, cannot be generalized: some people have this inclination, perhaps most people do not. If there is no general propensity to truck, barter and exchange then the emergence of the division of labour which is the 'necessary, though very slow and gradual consequence' of this propensity, and 'from which many advantages are derived' (117), remains unexplained. Or, is it a sufficient condition for the functioning of Smith's economic model to assure an increasing division of labour that, at least, some people have this propensity who organize the markets and define the rules of the 'economic game'? Although we have quite convincing models that suggest that the answer to this question may be positive, this is not what Adam Smith indicated.

However, it seems obvious that if markets are established throughout the economy and the invisible hand functions then the propensity to truck, barter and exchange is no longer needed either. Producers like the legendary baker will increase their prices and produce more if demand is larger than supply; and they will lower prices if they cannot sell the amount of goods they intended to sell, and produce less. If, in the longrun, the average price does not cover average costs, then the supplier will leave the market. The propensity to truck, barter and exchange has no specific function in this system.

It seems then that the propensity to truck, barter and exchange, which drives the engine that explains the 'nature and causes of the wealth of nations', does not generalize in Adam Smith theory: there is no space for it if markets function and a commercial society forms. Moreover, to some extent this inclination seems to be in conflict with the model of man which 
Adam Smith derives from his observations in his Theory of Moral Sentiments. Here we have sympathy and the impartial spectator.

In Smith's work there is a close link between sentiments and economic behaviour:

It is because mankind are disposed to sympathize more entirely with our joy than with our sorrow, that we make parade of our riches, and conceal our poverty. Nothing is so mortifying as to be obliged to expose our distress to the view of the public, and to feel, that though our situation is open to the eyes of all mankind, no mortal conceives for us the half of what we suffer. Nay, it is chiefly from this regard to the sentiments of mankind, that we pursue riches and avoid poverty. For to what purpose is all the toil and bustle of this world?' (Smith 1982 [1759, 1790]: 50).

To Adam Smith, economic life is, by and large, a matter of sentiments. But there is also

... the desire of bettering our condition, a desire which, though generally calm and dispassionate, comes with us from the womb, and never leaves us till we go into the grave... there is scarce perhaps a single instant in which any man is so perfectly and completely satisfied with his situation, as to be without any wish of alteration or improvement, of any kind (Smith 1981 [1776/77]: 341).

Smith refers to this desire to explain the motivation for the accumulation of capital by means of saving. It represents a disposition of 'man' which follows him throughout his life, 'though generally calm and dispassionate'. However, there is another motivation for the accumulation of capital: to become rich.

In Smith's view...man is inspired in commercial society to pursue the rewards of sympathy and the approbation through the means of acquiring wealth and property at the expense of seeking sympathy through virtuous behaviour. The pursuit of wealth thus tends to crowd out virtue as a means to be taken notice with sympathy (Verburg, 2000: 38).

The argument here is that there is no theory of social justice which permits us to evaluate the overall economic outcome. The implications and consequences of the economic system narrow down the application of the individualistic moral theory and corrupt its standards.

Models are meant to represent by resembling reality in certain respects and to certain degrees' (Mäki, 2005: 304). Although similarity is a major issue in model building, we have no explicit measure to express resemblance. In fact, the measure itself would be just another model with a new similarity problem attached to it. What is specific about economic models, 
and quite different to models in physics, is that reality tries to imitate models: managers talk about maximizing profits, politicians claim to maximize social welfare, and consumers defend their spending with references to preferences which form a 'transitive, reflexive, and complete' order. In general, model builders ignore that economic models 'fire back' to what they represent - models in physics do not (see Holler 1982, for a discussion). ${ }^{1}$

One of the consequences, which is vital for the interpretation of Adam Smith's moral philosophy, is that the definition of property rights is subject to the values of the commercial society. Contrary to Adam Smith's perspective to define wages which guarantee subsistence as a property right of workers that are protected by commutative justice, markets neither assure subsistence nor presuppose that workers can live from their wages and feed their families. Market economists do not accept property rights on wages which guarantee subsistence. But this omission of distributional justice is not in line with Adam Smith's word. I will come back to this argument.

First, however, in the next section, we will look at and discuss Adam Smith's Theory of Moral Sentiments and the model of man it contains. We will compare this model to one found in the Wealth of Nations. In section 3 , we confront the results with implications which derive from the propensity to truck, barter and exchange, on the one hand, and the market economy, on the other. Some conjectures about why a theory of social justice is missing in Adam Smith concludes the paper in section 4. Appendix A serves to clarify the concepts of sympathy, altruism and empathy, and the relationship between them. Appendix B contains Adam Smith's socioeconomic balance sheet.

\section{Sympathy}

The cornerstone of the model of man in Adam Smith's Theory of Moral Sentiments is sympathy which derives from the potential to put ourselves in the position of others to see things from their point of view. Sympathy is not restricted to altruistic fellow-feelings, although they might derive from it, but even allows for reflections about one's own conduct.

\footnotetext{
1 'The issue of resemblance is the hottest methodological issue in and about theoretical economics. Models and their assumptions are being criticised for being unrealistic and defended as sufficiently realistic or inconsequentially unrealistic ... The traditional complaint is that the representatives do not sufficiently resemble what they represent, and that the gap between the two is ignored by treating the substitute systems as if they were the real system' (Mäki 2005: 309).
} 
Pity and compassion are words appropriated to signify our fellow-feeling with the sorrow of others. Sympathy, though its meaning was, perhaps, originally the same, may now, however, without much impropriety, be made use of to denote our fellow-feeling with any passion whatever (Smith 1982 [1759, 1790]: 10).

It is not the passion of others which puts our sympathy in motion, but our hypothetical experience of being in the other person's position. ${ }^{2}$

Sympathy, therefore, does not arise so much from the view of the passion, as from that of the situation which excites it. We sometimes feel for another, a passion of which he himself seems to be altogether incapable; because, we put ourselves in his case, that passion arises in our breast from the imagination, though it does not in his from the reality. We blush for the impudence and rudeness of another, though he himself appears to have no sense of the impropriety of his own behaviour; because we cannot help feeling what confusion ourselves should be covered, had we behaved in so absurd a manner (Smith 1982 [1759, 1790]: 12).

More drastically, Adam Smith observes:

We sympathize even with the dead, and overlooking what is of real importance in their situation, that awful futurity which awaits them, we are chiefly affected by those circumstances which strike our senses, but can have no influence upon their happiness (Smith 1982 [1759, 1790]: 12).

This notion of sympathy differs substantially from David Hume's notion as the following quotation shows:

When I see the effect of passion in the voice and gesture of any person, my mind immediately passes from these effects to their causes, and forms such a lively idea of the passion, as is presently converted into the passion itself (Hume 1978 [1739]): 576).

In Hume, it is the other's experience and expression which triggers the fellow-feelings, in Smith the fellow-feelings are due to the other's situation or action. Hume's notion of sympathy implies a potential of altruistic (or spiteful-) fellow-feelings for the other. In principle, this does not concur with Adam Smith's notion of sympathy which is a feeling for oneself, and not for the other, although it presupposes a significant other. As quoted above: 'We blush for the impudence and rudeness of another, though he

\footnotetext{
2 'As we have no immediate experience of what other men feel, we can form no idea of the manner in which they are affected, but by conceiving what we ourselves should feel in the like situation' (Smith 1982 [1759]: 9).
} 
himself appears to have no sense of the impropriety of his own behaviour'.

Unfortunately, the notions of Hume and Smith get somewhat blurred when the other's situation or action is accompanied by observed passion then it is no longer obvious whether it is the passion or the situation of the other which induces our feelings. ${ }^{3}$

There are immediate consequences of Smith's notion of sympathy: the potential of self-evaluation and the pleasure of mutual sympathy. ${ }^{4}$ Let us first look at the potential of self-evaluation. Smith (1982 [1759, 1790]: 109) observes that the

principle by which we naturally either approve or disapprove our own conduct, seems to be altogether the same with that by which we exercise the like judgements concerning the conduct of the other people. We either approve or disapprove of the conduct of another man according as we feel that, when we bring his case home to ourselves, we either can or cannot entirely sympathize with the sentiments and motives which directed it. And in the same manner, we either approve or disapprove of our own conduct, according as we feel that, when we place ourselves in the situation of another man, and view it, as it were, with his eyes and from his station, we either can or cannot entirely enter into and sympathize with the sentiments and motives which influenced it. We can never survey our own sentiments and motives, we can never form any judgement concerning them; unless we remove ourselves, as it were, from our own natural station, and endeavour to view them as at a certain distance from us. But we can do this in no other way than be endeavouring to view them with the eyes of other people, or as other people are likely to view them.

Smith (1982 [1759, 1790]: 109) continues: 'We endeavour to examine our own conduct as we imagine any fair and impartial spectator would examine it'. It could be enough to argue that people follow this pattern and that is why sympathy allows for self-evaluation. Smith gives a further argument: 'In this, therefore, as well as in every other emotion, passion, and habit, the degree that is most agreeable to the impartial spectator is likewise most agreeable to the person himself ...' (Smith 1982 [1759, 1790]: 262). As we are social beings we do not ignore the judgment of others. On the contrary, we strive for their appreciation and are therefore willing to change our habits and our behaviour such that others can agree

\footnotetext{
3 This is perhaps the reason why Ken Binmore identified Adam Smith's concept of sympathy with David Hume's notion (see Binmore 1994: 21, 54ff.). He calls Smith as a pupil of Hume which, of course, suggests that their concepts of sympathy concur (Binmore 1998: 12). However, in this context, it seems more appropriate to consider Adam Smith a younger friend of Hume with the capacity of critique towards the older one.

${ }^{4}$ Here it seems that Smith (1982 [1759]: 13) borrows from the everyday notion of sympathy.
} 
with them.

The impartial spectator perspective, which derives from sympathy, thus becomes operational to evaluate, to control and to restructure our behaviour. It influences our conduct without identifying the evaluators, i.e. their judgments or, more specifically, their preferences or value systems. In modern terms, it could be understood as the result of a comparison of expected values. There is a certain equivalence between the unknown evaluators and Rawlsian veil of ignorance. In A Theory of Justice, Rawls (1972) repeatedly refers to Adam Smith impartial (sympathetic) spectator.

The impartial spectator is rather complex creature when applied to other persons. There is a 'first-person-plural perspective I share with all others to whom my judgment is implicitly addressed' (Darwall 1999: 160) and, secondly, I put myself into the shoes of the person being judged by me. 'When I make a moral assessment of someone's motive or feeling, according to Smith, I express a sympathy with it that I expect any one (of us) to share. I impartially project myself into that person's standpoint, not as myself but as any of us, and (attempt to) judge what any of us would be moved to do or feel if in that person's shoes' (Darwall 1999: 160).

The construct of an impartial spectator and the self-evaluation by means of sympathy presupposes that there is some common platform of experience in this society. This is what Adam Smith calls the pleasure of mutual sympathy (Smith 1982 [1759, 1790]: 262). Not friendly fellowfeelings triggers this pleasure but the fact that sympathy can work because of the common experience which the members of a society share. The common experience creates the familiarity, paired with universality, on which the impartial spectator functions (see Witztum 1999: 248).

Man, say they, conscious of his own weakness, and of need which he has for assistance of others, rejoices whenever he observes that they adopt his own passions because he is then assured of that assistance; and grieves whenever he observes the contrary, because he is then assured of their opposition (Smith 1982 [1759, 1790]: 13f).

If our passions (and thereby our evaluations and judgments) are confirmed by others then we feel good, although the passions as such can result from sorrows and pain. ${ }^{5}$

\footnotetext{
${ }^{5}$ Rawls (1972: 263) assumes unanimity and the original position is defined such that unanimity is possible. As he observes, this condition 'represents a constraint on arguments' and 'shapes the content of the theory of justice, the principles that are to match our considered judgements'. Rawls can 'afford' these constraints as his work is about the moral basis of society, and not about the conduct of individual people which is operational to Adam Smith
} 
Smith's moral sentiments require a 'moral community' (see Darwall 1999: 160) of common understanding and experience. Given such a community, it seems that, at least in the short run, we have no control of the pleasure of sympathy and the pain of opposition as they 'are always felt so instantaneously, and often upon such frivolous occasions, that it seems evident that neither of them can be derived from such self-interested consideration ...' '(Smith 1982 [1759, 1790]: 14). Even an ultimate hero like Lord Nelson could shed tears in a society which valued this expression of emotions rather highly. In a review essay in The New York Review of Books, Brewer (2005: 57) points out that the '... idea that the ability to express feelings had become a commonplace of eighteen century medical theory and philosophy'. Here Brewer refers to Adam Smith's Theory of Moral Sentiments and points to a 'cult of feeling' which came along with Georgian sentimentalism.

We could, however, easily construct an evolutionary model which illustrates that by the fact that pleasure results from a congruence of passion, there will be a convergence to 'shared feelings' if there is a common experience. ${ }^{6}$ But what guarantees common experience? In a society either characterized by hierarchy and social segmentation or the division of labour common experience can be scarce.

Moreover, we do not get a social ethics, i.e. a theory of justice, from the working of sympathy as described above, which permits us to evaluate social situation and generalize the result. The fact that all members of the society blush if $x$ prevails, given a common experience, does not imply that $x$ is bad, should be banned or forbidden, etc. There is no direct link in Adam Smith's moral theory which transforms the personal experience into a social value, even if this personal experience is shared by all members of the society. One reason is that the very same sensation ('expression of fear') can derive from various experiences and some of them cannot be subject of a moral evaluation. People express fear because nature threatens them ('Black Death') or because they are under the spell of a devilish dictator.

(see above).

6 The model could be constructed along the line of Binmore's $(1994,1998)$ theory of justice which focuses on common standards of evaluation to solve social coordination problems. Binmore claims that evolution has provided us with the capacity of the original position 'as an idealized representative of a class of equilibrium selection criteria washed up on the beach along with the human race by the forces of biological and social evolution'. He continues: 'Here is a tool supplied by Nature. Let us use it to improve our lives, just as we use whatever tools we find in our toolbox when making repairs around the house'. Thus, 'the plan is to widen the domain in which we make use of the device of the original position to coordinate our behaviour' and also to fight the people who 'pay lip service to the grand principles and utopian aims of traditional moralists' (Quotations from Binmore 1998: 9). 
In Adam Smith's writings the notion of self-interest does not necessarily coincide with the term egoistic or selfish as the above citation demonstrates. In most cases it can be paraphrased as 'focused on oneself. This seems to be obvious from the following quotation:

Sympathy ... cannot, in any sense, be regarded as a selfish principle. When I sympathize with your sorrows or your indignation, it may be pretended, indeed, that my emotion is founded in self-love, because it arises from bringing your case home to myself, from putting myself in your situation, and thence conceiving what I should feel in the like circumstances. But though sympathy is very properly said to arise from an imaginary change of situations with the person principally concerned, yet this imaginary change is not supposed to happen to me in my own person and character, but in that of the person with whom I sympathize (Smith 1982 [1759, 1790]: 317).

In today's use of the language it seems appropriate to substitute use of 'character' in this phrase with 'characteristics': they specify the personal and social conditions of the other, but not his or her value system.

When I condole with you for the loss of your only son, in order to enter into your grief, I do not consider what I, a person of such a character and profession, should suffer, if I had a son, and if that son was unfortunately to die: but I consider what I should really suffer if I was really you, and I not only change circumstances with you, but I change persons and characters. My grief, therefore, is entirely upon your account, and not at least upon my own (Smith 1982 $[1759,1790]: 317)$.

However, one might add, it is still my grief and has no immediate impact on how you feel about the loss of your son.

Smith observes that fellow-feeling, which is based entirely on the account of somebody else,

is not, therefore, in the least selfish. How can that be regarded as a selfish passion, which does not arise even from the imagination of anything that has befallen, or that relates to myself, in my own proper person and character, but which is entirely occupied with what relates to you? A man may sympathize with a woman in child-bed; though it is impossible that he should conceive himself as suffering her pains in his own proper person and character. That whole account of human nature, however, which deduces all sentiments and affections from self-love, which has made so much noise in the world, but which, so far I know, has never yet been fully and distinctly explained, seems to me to have arisen from some confused misapprehension of the system of sympathy (Smith 1982 [1759, 1790]: 317). 


\section{Self-interest, market society, and the invisible hand}

Although the tears I may spread 'when I condole with you for the loss of your only son, in order to enter into your grief, cannot be an expression of selfishness, they do not contradict that I am self-interested. For example, if I suffer from such emotional experiences I could try to avoid situations which are strongly connected with such experiences. Self-interest plays a minor role in The Theory of Moral Sentiments, but it is standard to consider to be a cornerstone of The Wealth of Nations. However, as we see from the quotation in the introduction of this paper, the dynamics of Smithian economy does not derive from self-interest but from a 'certain propensity of human nature' ... 'the propensity to truck, barter and exchange one thing for another' (Smith 1981 [1776/77]: 25). The division of labour follows from this propensity, and a substantial increase of productivity and 'opulence' are results of the division of labour. ${ }^{7}$ From this further division of labour and more opulence follows.

Obviously, self-interest is conditional to this scheme. The core of this scheme is the model of man which presupposes 'the propensity to truck, barter and exchange one thing for another'. Of course, this propensity can be observed, but is it shared by many people? Is it a 'necessary consequence of the faculties of reason and speech' (Smith 1981 [1776/77]: $25)$ ? If there are serious doubts that this propensity is so general a human feature as proposed by Smith, one might still argue that it suffices if some people in a society have this inclination. Then, however, one has to show how this inclination becomes prominent for the development of the economy.

However, let us assume that we all share this propensity. Does the division of labour and opulence follow? Empirically, we have to observe that the propensity to truck, barter and exchange differs in various cultures, but it is far from obvious that a stronger inclination leads to more division of labour and opulence. Theoretically, the arguments given by Adam Smith are not conclusive. Why should the propensity to truck, barter and exchange lead to a growing division of labour? Of course, the division of labour implies a potential for exchange - without exchange the division of labour does not work. But from this we cannot conclude that the mere fact (or assumption) of a propensity to exchange create an increasing division

\footnotetext{
7 'This division of labour, from which so many advantages derived, is not originally the effect of any human wisdom, which foresees and intends that general opulence to which it gives occasion. It is the necessary, though very slow and gradual consequence of a certain propensity of human nature which has in view no such extensive utility; the propensity to truck, barter and exchange one thing for another' (Smith 1981 [1776/77]: 25).
} 
of labour, or establish markets. ${ }^{8}$ In fact, one could argue that with an increasing division of labour barter and exchange become more trivial and satisfy less our inclination (if it exists). In general, goods from an assembly line are not subject to barter, but traded on markets.

It is obvious that Adam Smith's proverbial baker does not produce his bread because of an inclination for barter and exchange, but out of selfinterest and because there is demand for it such that he can make some profit. This profit gives him the means to obtain goods that he does not produce himself, although he is in want of them for consumption or investment. Markets create anonymity; there are buyers, sellers, goods and prices. If markets function, there is no need and no empty space for barter and exchange. Self-interest and the set of rules which determine the organization of a market (plus perhaps the physical needs) seem to be sufficient. However, is the market a consequence of self-interest and is there an inherent tendency of the market economy to expand and thus to support an increase of the division of labour? If we can justify a 'yes' to both questions, then we have an explanation for the growing market economy that Smith proposes in the Wealth of Nations. Of course, these questions touch on problem of the origin of markets. Obviously, selfinterest is an essential ingredient to the function of the market, but also fuelled economies which did not focus on the market. In the classical period of Greece and Rome, the members of the political and social elite owned land which was used to grow food and to deliver other necessities of life. Productions relied on slaves. The interest of the landowners was autarky. Only surpluses were brought to the market and, in good days, the revenues were spent on luxury goods. The latter were considered presents of fortuna. A similar pattern prevailed in Northern Europe before the Industrial Revolution. ${ }^{9}$

A prominent feature of a self-sufficient economy is that, contrary to the implication of neoclassical models of production and consumption,

\footnotetext{
${ }^{8}$ Karl Polanyi (1968 [1944]: 61) concludes that 'individual acts of barter or exchange this is the bare fact - do not, as a rule, lead to the establishment of markets in societies where other principles of economic behaviour prevail'.

9 There is ample evidence for pre-history (see Schwedenspeicher at Stade, Northern Germany). However, in England, 'by 1315 the countryside was full, busy and making money. Farming was becoming more sophisticated and trade-oriented, well-managed hay meadows produced a good flow of cash, and eight to ten million sheep supplied wool for the export trade alone' (Jones and Ereira 2005: 28). The duties of the villages towards the lords of the manor had often been replaced by money rents: nearly 90 per cent of the lords income were paid in cash. This rural market society was crushed by the great famine in 1315 and the Back Death of 1348. As labour became scarce, the lords threw the expensive peasants off their land and replaced them with sheep. Again, trade became a phenomenon of periphery with moderate impact on everyday life.
} 
neither the allocation of inputs, especially of labour, nor the use of the produce depend on market prices and their variation. This was part of the independence which, in Republican Athens distinguished a full-fledged citizen of the first class, from members of lower classes. In Rome, Senators and other members of the ruling class were meant to plough their own land, or, at least, claim to do so, together with their slaves. In what we call pre-industrial time, 'as a rule, the economic system was absorbed in the social system, and whatever principle of behaviour predominated in the economy, the presence of the market pattern was found to be compatible with it' (Polanyi 1968 [1944]: 68). 'Up to the end of the eighteenth century, industrial production in Western Europe was a mere accessory to commerce' (Polanyi 1968 [1944]: 74).

Moreover, with a look into history, Karl Polanyi summarizes that 'the principle of barter or exchange ... revealed no tendency to expand at the expense of the rest' 1968 [1944]: 68). This observation contradicts the conclusion which Adam Smith drew on the expansion of division of labour that was fuelled by the 'propensity to truck, barter and exchange one thing for another'. Polanyi (1968 [1944]: 57) maintains that ' $\ldots$ the gearing of markets into a self-regulating system of tremendous power was not the result of any inherent tendency of markets towards excrescence, but rather the effect of highly artificial stimulants administered to the body social in order to meet a situation which was created by the no less artificial phenomenon of the machine'. Clearly, it would be interesting to discuss what these 'highly artificial stimulants' are and how they work, but they are not part of Adam Smith's economic system, although it presupposed regulation of markets such that the competitive forces sustain and do not give way to monopoly, collusion or chaos. This is obvious from his chapter on banking (see Book II, Chapter II in the Wealth of Nations).

The invisible hand needs the help of a regulating authority to do its job. Adam Smith did not in general assume that markets regulate themselves. Obviously, the concept of a self-regulating market economy transgresses the borders of the economic sector to which Adam Smith, more or less, confined the working of the invisible hand. As stated by Polanyi (1968 [1944]: 71), 'a self-regulating market demands nothing less than the institutional separation of society into an economic and political sphere'. However, the economic sphere will become dominant for society, since 'a market economy can only exist in a market society. ... A market economy must comprise all elements of industry, including labour, land, and money' (Polanyi 1968 [1944]: 71). ${ }^{10}$ 'The extreme artificiality of market

\footnotetext{
${ }^{10}$ Polanyi (1968 [1944]: 69) concludes that 'Self-regulation implies that all production is for sale on the market and that all incomes derive from such sales'. ...'Nothing must be
} 
economy is rooted in the fact that the process of production itself is here organized in the form of buying and selling' (Polanyi 1968 [1944]: 71).

In Adam Smith, production itself is also organized in the form of 'buying and selling'. This is a consequence of the division of labour combined with the 'propensity to truck, barter and exchange'. It does not necessarily follow that this principles carry over to other branches of society, but it is difficult to see how the social life of the working people should not be affected in its essence by the 'buying and selling' of labour. This is the root of Karl Marx's well-known critique of the capitalist system, but also, from a quite different angle, the point of departure of John Ruskin's cultural theory. ${ }^{11}$

It seems that Adam Smith was quite aware of the conflict between the division of labour and the model of man that he suggested in his Theory of Moral Sentiments. In the Wealth of Nations we can read:

In the progress of the division of labour, the employment of the far greater part of those who live by labour, that is, of the great body of the people, comes to be confined to a few very simple operations; frequently to one or two. But the understandings of the greater part of men are necessarily formed by their ordinary employments. The man whose whole life is spent in performing a few simple operations, of which the effects too are, perhaps, always the same, or very nearly the same, has no occasion to exert his understanding, or to exercise his invention in finding out expedients for removing difficulties which never occur. He naturally loses, therefore, the habit of such exertion, and generally becomes as stupid and ignorant as it is possible for a human creature to become (Smith 1981 [1776/77]: 781f).

He concludes 'this is the state into which the labouring poor, that is, the great body of the people, must necessarily fall, unless government takes some pains to prevent it'.

Smith brings forward two major arguments why the public should be interested in the education of the 'common people'. The first is to support

allowed to inhibit the formation of markets, nor must incomes be permitted to be formed otherwise than through sales'.

${ }^{11}$ In The Stones of Venice, Ruskin (2001 [1851/53]) developed the relationship between 'valuable labour' and the gothic style. His starting point is a critique of the division of labour: 'We have much studied and much perfected, of late, the great civilized invention of the division of labour: only we give it a false name. It is not, truly the division of labour that is divided; but the men - Divided into mere segments of men - broken into small fragments and crumbs of life; so that all the little piece of intelligence that is left in a man is not enough to make a pin, or a nail, but exhausts itself in making the point of the pin or the head of the nail' (Quoted in Anthony 1993: 55). An alternative approach to labour is elaborated in his Unto This Last, subtitled Four Essays on the First Principles of Political Economy (Ruskin 1970 [1862]). 
or to maintain the martial spirit of the great body of the people, which is necessary to defend the country and assure the security of its citizens, and to increase their power of judgement and resistance against

the delusions of enthusiasm and superstition, which among ignorant nations, frequently occasion the most dreadful disorder. An instructed and intelligent people besides are always more decent and orderly than an ignorant and stupid one. They feel themselves, each individually, more respectable, and more likely to obtain the respect of their lawful superiors, and they are therefore more disposed to respect those superiors. They are more disposed to examine, and more capable of seeing through, the interested complaints of faction and sedition, and they are, upon that account, less apt to be misled into any wanton or unnecessary opposition to the measures of government. In free countries, where the safety of government depends very much upon the favourable judgment which the people may form of its conduct, it must surely be of the highest importance that they should not be disposed to judge rashly or capriciously concerning it (Smith 1981 [1776/77]: 788).

However, not every government is likely to profit from the 'judgment which the people may form of its conduct', combined with a 'martial spirit'.

The second argument is Smith's belief that public education could compensate for the increasing alienation inherent to the division of labour and to overcome the 'drowsy stupidity' (Smith 1981 [1776/77]: 783) which tends to result from it. However, as stated by Emma Rothschild (2001: 98), for Adam Smith 'education is more generally something which is not only useful ... but also amusing'. She concludes, for Adam Smith, 'government supported education is in no sense something which is itself needed in the interest of commercial prosperity. It is consequence of economic advancement, and not a requirement for further advancement' (Rothschild, 2001: 98).

\section{The missing book}

The above discussion demonstrates that while Adam Smith's economic theory prescribes and assumes social institutions like the market and the government, his moral theory is limited to the evaluation of individual behaviour. ${ }^{12}$ It is therefore inadequate to evaluate the results and possible

\footnotetext{
${ }^{12}$ Darwall (1999: 162) argues that 'for Smith, justice is not just a virtue of societies, but also, crucially, of individuals'. Since, for Smith, 'a judgement of justice must be anchored in moral sentiments' Darwall (1999: 162) there can only be social justice if there is justice on the individual level. However, there can be justice on the individual level and no valid concept of justice that holds for the corresponding society.
} 
outcomes implied in his economic theory. For instance, it does not allow us to derive moral principles for the evaluation of the distribution of income or wealth, or to discuss the perhaps conflicting interests of labour, capital and land owners.

To some extent, this shortcoming reflects that Adam Smith did never accomplish the third book of his grand scientific scheme dedicated to the analysis of the State (or, equivalently, the Law). ${ }^{13}$ In the closing lines of The Theory of Moral Sentiments he states:

I shall in another discourse endeavour to give an account of the general principles of law and government, and of the different revolutions they have undergone in the different ages and periods of society, not only what concerns justice, but in what concerns police, revenue, and arms, and whatever else is the object of law (Smith 1982 [1759, 1790]: 342).

Why did he never accomplish this work? In the 'Advertisement', which introduces the sixth edition of The Theory of Moral Sentiments published in 1790, the year of his death, Smith refers explicitly to the above quote commenting:

In the Enquiry concerning the Nature and Causes of the Wealth of Nations, I have partly executed this promise; at least so far as concerns police, revenue, and arms. What remains, the theory of jurisprudence, which I have long projected, I have hitherto been hindered from executing, by the same occupations which had till now prevented me from revising the present work. Though my advanced age leaves me, I acknowledge, very little expectation of ever being able to execute this great work to my satisfaction; yet, as I have not altogether abandoned the design, and as I wish still to continue under the obligation of doing what I can, I have allowed the paragraph to remain as it was published more than thirty years ago, when I entertained no doubt of being able to execute every thing which it announced (Smith 1982 [1759, 1790], no page number).

Of course, in the literature, we find, more or less profound, speculations about the 'occupations which had till now prevented me from revising the present work'. His biographers repeatedly mention that he was quite exhausted after he finished the Wealth of Nations. Moreover, in the following years he suffered from the death of dear friends and very close family members. Smith's mother died in 1784 and his cousin Janet Douglas in 1788. This could be one explanation, another of course is that he had no convincing idea how to close the gap between his economic

\footnotetext{
${ }^{13}$ The scheme of three books is somehow reflected in Smith's Lectures on Jurisprudence.
} 
theory and his moral theory. He might have contented himself with the argument that in times of extreme scarcity and starvation that the number of people who achieve an income above subsistence is quite a good indicator of the wellbeing of a society - and an evaluation of the distribution of income and wealth or the discussion of control over the means of production can be postponed. ${ }^{14}$

Subsistence, however, can also be interpreted as the measure rod for social justice. Witztum (1999: 255) argues that Adam Smith 'would agree with considering the failure of distributing subsistence as a violation of justice in its commutative sense (i.e. requiring positive reprisal)' as it 'will create harm and injury, not only through labourer's frustrated expectations, but through physical and mental hardship as well' (Witztum 1999: 256)..$^{15}$ In the Theory of Moral Sentiments we can read that

we are said to do justice to our neighbour when we abstain from doing him any positive harm, and not directly hurt him, either in his person, or in his estate, or in his reputation. This is that justice which I have treated of above, the observance of which may be extorted by force, and the violation of which exposes to punishment (Smith 1982 [1759, 1790]: 269).

Not doing harm includes the non-violation of property rights which are the consequence of the principle of stable possession. ${ }^{16}$ The resentment, as a result of the violation, and which is 'sympathized with by the impartial spectator is the basis of punishment' (Salter 1994: 302).

\footnotetext{
${ }^{14}$ Modern thinkers, sometimes based on Adam Smith, point to the potential to derive a theory of justice from sympathy. John Rawls (1972: 184) asks us to 'consider the following definition reminiscent to Hume and Adam Smith. Something is right, a social system say, when an ideally rational and impartial spectator would approve of it from a general point of view should he possess all the relevant knowledge of the circumstances. A rightly ordered society is one meeting the approval of such an ideal observer'. As Rawls himself pointed out there are several problems with this definition.

${ }^{15}$ This injury will trigger widely shared resentment. 'Resentment seems to have been given us by nature for defence, and for defence only. It is the safeguard of justice and the security of innocence' (Smith 1982 [1759, 1790]: 79).

16 To Adam Smith stability and protection against unexpectedness and surprise are positive values as such. In his manuscript, The History of Astronomy, which Joseph Black and James Hutton published post mortem he demonstrated that human beings are ill-prepared for experiencing surprises, especially when the object should be a reason for joy and pleasure. '.. when the object is unexpected; the passion is then poured in all at once upon the heart, which is thrown, if it is a strong passion, into the most violent and convulsive emotions, such as sometimes cause immediate death; sometimes, by the suddenness of the extacy, so entirely disjoint the whole frame of imagination, but it never after returns to the former tone and composure, but falls either into a frenzy or habitual lunacy; and such as almost always occasion a momentary loss of reason, or of that attention to other things which our situation or our duty requires' (Smith 1982: 34f).
} 
If we follow this line of argumentation in Salter (1994) then it follows that Adam Smith's specifications of property right are subject to social conventions. His definition of justice implies abstaining from taking what others already rightfully and legally possess, however, what is meant by rightfully and legally is subject to the impartial spectator. Given the violation of subsistence and the sentiments which it arouses, Witztum (1999: 248) concludes that 'both familiarity and universality of such sentiments in the age of commercial society would have guaranteed the impartial spectator's approval of their resentment and would demand an enforced recompense'. This, however, can be questioned if the outcome of the invisible hand, i.e. the market economy, private property, free trade and division of labour, has achieved the status of the law of nature (or of divine order).

Universality and familiarity are 'socially dependent and relative' (Witztum 1999: 248). The self-declared prophets of the Wealth of Nations have successfully worked on a reinterpretation of Adam Smith's theory to achieve this goal, and the impartial spectator's view and sympathy changed accordingly (see Rothschild, 2001). If there are resentments because subsistence is not achieved, then they will be weak and most likely there will be no call for dramatic action or reprisal. This is, of course, supported by the fact that the invisible hand is impersonal and it is difficult to focus resentments on, for example, the 'capitalist system'.

One should add that Adam Smith was quite aware that subsistence by appropriating the fruits of labour is not guaranteed even in societies of some surplus with the consequence of 'destroying a great part of the children which their fruitful marriages produces' (Smith 1981 [1776/77]: 98). Consequently, Witztum (1999: 259) concludes, ' ... such an organisation of society will clearly be unjust'. However, in Adam Smith's work we do not find a recipe of how to overcome this injustice (if not by economic growth which makes labour scarce and pushes wages above subsistence). Moreover, can we conclude that a distribution of income is just if it does not violate subsistence for labour?

A brief review of modern moral philosophy shows that the book that Adam Smith meant to write is still missing. In his very influential 'Anarchy, State and Utopia', Robert Nozick (1974) mimics the market to derive a 'minimum state' mainly restricted to produce security within its domain and protect its citizens from outside aggression. Applied to the market economy, the state guarantees the necessary degree of 'safety rules' such that the market can function. Consequently, market results are sui generis 'justified and just' if competition works: justice derives from the invisible hand. Of course, this theory is inadequate to compare alternative market outcomes, not to speak of results which do not derive from markets.

While Nozick's theory is based on the construct of an anonymous 
interaction of people via the market, Ken Binmore's theory of justice (Binmore 1994, 1998) refers to bilateral interaction, face-to-facebargaining, and an evolution of common standards of evaluation which derives from these possibly repeated relationships. His theory ignores the forming of groups, unions, associations, parties, etc., which become relevant whenever more than two people interact. As long as people act solely as individuals and meet in pairs, Binmore's theory seems a relevant contribution. However, it is not obvious why the principles of human conduct which derive from such a theory should carry over into a world which is dominated by social entities (i.e. coalitions) such as firms, trade unions, clubs, and political parties. The standards of evaluation, which result from the bilateral bargaining model could justify a specific income distribution that could never result from a society with a coalition structure. Technically speaking it could well be that the result from bilateral bargaining is not in the core, and therefore not feasible without the intervention of an external authority. However, why should the authority intervene to guarantee a result which is justified by bilateral bargaining when the society is structured in coalitions?

Rawls' theory of justice (Rawls 1972) became popular and even entered textbooks of microeconomics because it allowed for the evaluation of income distributions. Its well-known and somewhat vulgarized maximin implication says that we should prefer a society $A$ to a society $B$ if the least advantaged citizen (or group of citizens) is worse off in $B$ than in $A$, irrespective of whether the average income of $\mathrm{B}$ is larger or smaller than $A$. Given that the average income forms an expectation behind a veil of ignorance, its disregard triggered substantial criticism. ${ }^{17}$ Another problem is that people might accept Rawls' 'two principles of justice', yet, still reject the maximin principle for evaluating social outcomes as it may violate the implications of sympathy. Adam Smith repeatedly pointed out that people have a '.. disposition to admire, and almost to worship, the rich and the powerful, and to despise, or, at least, to neglect persons of poor and mean condition ...' (Smith 1982 [1759, 1790]: 61).

\section{Appendix A: Sympathy, altruism, and empathy}

Let us assume that $u_{i}(\cdot)$ expresses the (personal) utility function of agent $i$ and $u_{j i}(\cdot)$ represents agent $j$ 's (personal) utility function as assumed by $i$. The situation (position) of $i$ and $j$ is summarized by $s_{i}$ and $s_{j}$, respec-

\footnotetext{
${ }^{17}$ See, e.g. the discussion in the Quarterly Journal of Economics 88, 1974, which almost immediately followed the publication of A Theory of Justice (Rawls 1972).
} 
tively. Then we can write sympathy, altruism and empathy as follows:

$$
\begin{array}{ll}
\text { Sympathy } & u_{i}\left(s_{i}, s_{j}\right) \text {, with partial sympathy given by } u_{i}^{\prime}\left(s_{j}\right) .{ }^{18} \\
\text { Altruism } & u_{i}\left(s_{i}, u_{j i}\left(s_{j}\right)\right) \text {, with pure altruism given by } u_{i}^{*}\left(u_{j i}\left(s_{j}\right) .\right. \\
\text { Empathy } & u_{i k}\left(s_{i}\right)>u_{j k}\left(s_{j}\right) \text {, with } k \text { as the un-involved observer. }
\end{array}
$$

What seems more plausible: $u_{i k}\left(s_{i}\right)>u_{j k}\left(s_{j}\right)$ or $u_{k}\left(s_{i}\right)>u_{k}\left(s_{j}\right)$ ?

Binmore (1994 1998) illustrates the working of empathy for the case of Adam and Eve: If Adam and Eve are represented by $k$ and $i$, respectively, $u_{i k}\left(s_{i}\right)$ implies that Adam is the un-involved observer who needs to imagine himself in her shoes with her preferences (and her beliefs). Thus, starting from the self-centered preference relation $u_{k}\left(s_{k}\right)$, empathy implies a perfect substitution of roles and preferences with the qualification that $u_{i k}(\cdot)$ does not express the preferences of $i$ but the preferences of $i$ perceived by $k$. If this substitution works then it should be possible that Adam is in a position to compare the two alternative situations which could be relevant for Eve: (1) Eve enjoying the apple, represented by $s_{i}^{\circ}$, and (2) Eve enjoying a fig leaf, represented by $s_{i}^{*}$. A possible result of this comparison is $u_{i k}\left(s_{i}^{\circ}\right)>u_{i k}\left(s_{i}^{*}\right)$ with the consequence vividly illustrated in Massaccio's 'The Expulsion of Adam and Eve from Paradise' in the Brancacci Chapel of Santa Maria del Carmine at Florence.

Adam Smith's impartial spectator combines agent $i$ 's sympathy with the empathetic preferences of others, $k$, directed to his or her own position, $s_{i}$. It seems that $i$ 's reaction on the assumption of an impartial spectator can be described by $\max u_{i}\left[u_{i k}\left(s_{i}\right)\right]$, the maximum $i$ gains from the $k$ 's evaluations of $i$ 's situation. Note that while $u_{i k}\left(s_{i}\right)>u_{j k}\left(s_{j}\right)$ compares $k$ 's empathetic preferences of two individuals $i$ and $j$, related to their corresponding situations $s_{i}$ and $s_{j}, u_{i k}\left(s_{i}^{*}\right)>u_{i k}\left(s_{i}^{*}\right)$ expresses $k^{\prime} s$ empathetic preferences of individual $i$ being in situations $s_{i}^{\circ}$ and $s_{i}^{*}$, respectively.

\section{Appendix B: Adam Smith's socio-economic balance sheet}

The following 'balance sheet' tries to summarize the hypothesis presented in this paper. It has been argued that Adam Smith did not develop a theory

\footnotetext{
${ }^{18}$ Here we make the rather plausible assumption that the sympathy we have towards $j$, based on $j$ 's position, depends on our own situation. As a consequence, $u_{i}^{\prime}\left(s_{j}\right)$ is valid for a given $s_{i}$.
} 
of social justice which is applicable to a society that is no longer constrained by the subsistence level income of the major part of its workforce with the possibility of starvation and early death in the case of economic stagnation or recession. Adam Smith's moral theory describes how an individual acquires his or her moral standard in the society he or she lives in. However, it does neither tell us how the society develops its moral standards nor does it propose a procedure or basis of values which allows to derive standards of social justice. For example, unlike Rawls' Theory of Justice (Rawls 1972), we do not find theoretical arguments in Adam Smith that suggest an evaluation of the distribution of income or wealth. This is not to say that Adam Smith had no distributional concern, but that he did not develop a corresponding theory of it. ${ }^{19}$

Table 1 Adam Smith's socio-economic balance sheet

\section{Ethics}

Moral theory: moral sentiments, sympathy, impartial spectator

\section{Economics}

Propensity to truck, barter and exchange one thing for another

Division of labour

Market economy

Market society

We already stated that Smith assumption of a 'propensity to truck, barter and exchange one thing for another' is not only questionable, but it also loses its relevance if the market functions. The division of labour and the 'invisible hand' of the market are the main ingredients of a commercial society. What Adam Smith did not see or expect, however, is that the principle of the commercial society tends to invade parts of our society which are, prima vista, not considered within the domain of the economy. The resulting market society is characterized by competition and selfregulation in all aspects of life. Inasmuch as production is concerned, 'selfregulation implies that all production is for sale on the market and that all incomes derive from such sales. ... Nothing must be allowed to inhibit the formation of markets, nor must incomes be permitted to be formed otherwise than through sales' (Polanyi 1968 [1944]: 69).

\footnotetext{
${ }^{19}$ Verburg (2000: 23) maintains that 'the extent of Smith's distributional concern is still being underestimated'.
} 
Alternatively, Werner Sombart suggested the implementation of the capitalist model designed by Adam Smith will result in a division of labour within the enterprise, 'especially as between the functions of ownership and management on the one hand, and those of carrying out orders on the other' (Parsons 1928: 647). In its mature phase, it will turn into the form of 'Spätkapitalismus' which is dominated by 'a 'monster', the capitalist enterprise, possessed of a purpose, an understanding, and a set of virtues of its own, going its own way independently of human will' (Parsons 1928: 651).

\section{Acknowledgements}

I would like to thank Matthew Braham, Leonidas Donskis, the participants of the Tartu conference, December 2005, and of the Salem College (Mass.) lecture, September 2005, for helpful comments.

\section{References}

Anthony, P.D. (1983), John Ruskin's Labour. A Study of Ruskin's Social Theory, Cambridge University Press.

Binmore, K. (1994), Playing Fair, Game Theory and the Social Contract vol. I, The MIT Press.

Binmore, K. (1998), Just Playing, Game Theory and the Social Contract vol. II, The MIT Press.

Brewer, J. (2005), The return of the imperial hero, New York Review of Books 52 (November 3): 55-58.

Darwall, S. (1999), Sympathetic liberalism: Recent work on Adam Smith, Philosophy and Public Affairs 28: 140-163.

Holler, M.J. (1982), Models in natural and social sciences, Journal of Mind and Behavior 3: 43-53.

Holler, M.J. (1986), Moral sentiments and self-interest reconsidered, in: A. Diekmann and P. Mitter (eds.), Paradoxical Effects and Social Behaviour: Essays in Honor of Anatol Rapaport, Physica-Verlag.

Hollis, M (1977), Models of Man: Philosophical Thoughts on Social Action, Cambridge University Press.

Hume, D. (1978 [1739]), A Treatise of Human Nature, 2nd ed., edited by L.A. Selby-Bigge, revised by P. Nidditch, Oxford University Press.

Jones, T. and A. Ereira (2005), Terry Jones' Medieval Lives, BBC Books.

Mäki, U. (2005), Models are experiments, experiments are models, Journal of Economic Methodology 12: 303-315.

Nozick, R. (1974), Anarchy, State and Utopia, New York: Basic Books.

Parsons, T. (1928/29), 'Capitalism' in recent German Literature: Sombart and Weber, doctoral dissertation, published in The Journal of Political Economy 36: 641-661, and 37: 31-51.

Polanyi, K. (1968 [1944]), The Great Transformation: The Political and Economic Origin of our Time, Beacon Press. 
Rawls, J. (1972), A Theory of Justice, Oxford University Press.

Rothschild, E. (2001), Economic Sentiments, Adam Smith, Condorcet, and the Enlightenment, Harvard University Press.

Ruskin, J. (2001 [1851/53]), The Stones of Venice, The Folio Society.

Ruskin, J. (1970 [1862]), 'Unto This Last': Four Essays on the First Principles of Political Economy, Collins Publishers.

Salter, J. (1994), Adam Smith on justice and distribution in commercial societies, Scottish Journal of Political Economy 41: 299-313.

Smith, A. (1982 [1759, 1790]), The theory of moral sentiments, in: D.D. Raphael and A.L. Macfie (eds.), Glasgow Edition of the Works and Correspondence of Adam Smith vol. I, Liberty Press.

Smith, A. (1981 [1776/77]), An inquiry into the nature and causes of the wealth of nations, in: R.H. Campbell and A.S. Skinner (eds.), Glasgow Edition of the Works and Correspondence of Adam Smith vol. II, Liberty Press.

Smith, A. (1982 [1762-1766]), Lectures on jurisprudence, in: R.L. Meek, D.D. Raphael and P.G. Stein (eds.), Glasgow Edition of the Works and Correspondence of Adam Smith vol. V, Liberty Press.

Smith, A. (1982), The history of astronomy. Essays on philosophical subjects, in: W.P.D. Wightman and J.C. Bryce (eds.), Glasgow Edition of the Works and Correspondence of Adam Smith vol. III, Liberty Press.

Verburg, R. (2000), Adam Smith's growing concern on the issue of distributive justice, European Journal of the History of Economic Thought 7: 23-44.

Witztum, A. (1997), Distributive considerations in Smith's conception of economic justice, Economics and Philosophy 13: 241-259. 